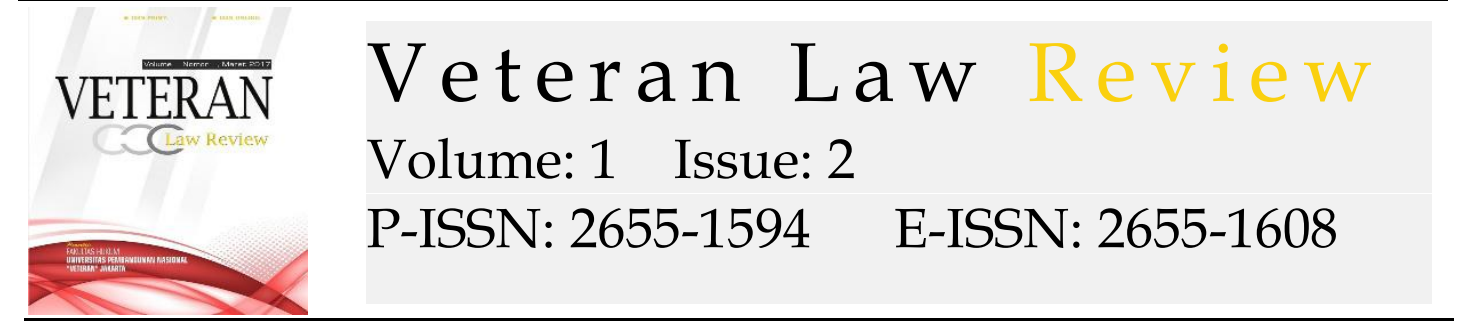

\title{
Criminal Law Protection On Online Victims Of Victims
}

\section{Safaruddin Harefa}

Study Program of Law, Mohammad Natsir University of Bukittinggi, E-mail: safaruddinharefa1993@gmail.com

\begin{tabular}{|c|c|}
\hline ARTICLE INFO & ABSTRACT \\
\hline $\begin{array}{l}\text { Keywords: } \\
\text { Legal Protection, } \\
\text { Criminal, Business, } \\
\text { Online. } \\
\text { How to cite: } \\
\text { Harefa, Safaruddin, } \\
\text { (2019). Criminal Law } \\
\text { Protection On Online } \\
\text { Victims Of Victims } \\
\text { Veteran Law Review. 2(1). } \\
\text { 33-45 }\end{array}$ & $\begin{array}{l}\text { This study aims to find out and analyze how criminal law } \\
\text { protection for victims of online businesses. This study uses a } \\
\text { juridical normative law research with secondary legal } \\
\text { materials, namely analyzing the study of legislation and cases. } \\
\text { The results of the research that the authors get are that } \\
\text { criminal legal protection against victims of online business } \\
\text { crime in accordance with existing laws and regulations should } \\
\text { guarantee the existence of victims' rights from online } \\
\text { businesses. The rights that must be obtained by online } \\
\text { business victims are contained in Law Number } 31 \text { Year } 2014 \\
\text { concerning Amendments to Law Number } 13 \text { Year } 2006 \\
\text { concerning Witness and Victim Protection and Law Number } \\
\text { 11 Year } 2008 \text { Information and Electronic Transactions (ITE ) } \\
\text { That the rights that have been guaranteed have not run } \\
\text { optimally are carried out because the rules governing the } \\
\text { protection of consumers of online businesses have not been } \\
\text { detailed in a Legislation and do not provide space for victims } \\
\text { to obtain criminal legal protection. } \\
\text { Copyright @2019 VELREV. All rights reserved. }\end{array}$ \\
\hline
\end{tabular}

\section{Introduction}

The Information Technology takes an important role for both in the present and in the future. It is believed for bringing a great benefit and interest to all countries in the world. There are at least 2 things that make this technology is so important in supporting the Economic Growth in the world. First, it drives the demand of information technology products itself, such as Computers, Modems, the facilities for supporting the internet networks and so on. Second, it is easy to do a business transaction, especially in financial business, in addition to other general business. ${ }^{1}$

In this era which is very modern until now, the internet becomes a part which is cannot be separated from our daily lives. In Indonesia, Internet has been begun since in 1990s. People used the internet were still limited at that time, they usually used it in the big cities. The great information technology development caused a new style in the trading system. At these recent years,

${ }^{1}$ Agus Raharjo (2002). Cyber Crime Pemahaman dan Upaya Pencegahan Kejahatan Teknologi, Bandung: PT. Citra Aditya Bakti, p. 1. 
the online trading business is increasingly prevalent in Indonesia, such as Berniaga.com, Toko Bagus, and also many online shops which is used Facebook or any Handphone or Smartphone as its marketing tool. The Online Business is a kind of Business which is done via internet as a marketing media, with using websites as their Catalogues. ${ }^{2}$

In this time, the online business is greatly spread and have a great trending in Indonesia, not only for the certain items but also for the world-class items. This business is considered as a very potential business and it have a great chance to achieve great profits because many benefits that can be obtained in running this business such as how to order something which is simple and not complicated and also its price is relatively affordable and they can compete with the ordinary business. In addition, this business does not need any places to sell their product such as shops, stalls and many more, but they just sell it through social media, blog, or other media related to the internet.

But the Negative impact can be occurred because the influence of internet media users in this social environment until now. Through internet, there are several types of criminal acts what are easily to do so, such as the criminal of defamation, pornography, gambling bankruptcy, destruction of cyber networks, the attacks through virus and many more, ${ }^{3}$ but the recent impact occurred is many frauds or fakes that haunt Indonesian lately, started from lower until the top-class societies.

The number of crimes occurred in Indonesia have many victims through frauds or fakes in doing an online transaction or other else. In this time, the writer takes the latest case until now, that is the example of some cases which has been done until now, such as a student who was a victim of the fake online business. Sugi, 24, admitted that he was tricked by someone claiming to sell laptops. At first, he would buy it. But after he searched it in Internet, he got what he wanted in an online shop website. "at that time, I exchanged our BlackBerry Messenger contacts and I made our trading transactions." Said a student who study at one of university in Sleman on Friday $(25 / 3 / 2016)$. He believed this person because he updated his social media status about his online trading transactions every hour. And sometimes, he posted some testimonies or said thank you for his buyer. Also he said that he had sent many goods or items to the buyer's destination until he uploaded the shipping receipts that are not yet known. "so I think his status is quite convincing." He said. At last, there was an accord to buy a laptop which costs 5 million rupiah. His money was sent through transferring to his bank account. After that, the suspect sent a picture of the laptop that wanted to be sent via shipping service. He started to realize that he was a victim of fake online business two weeks after he transferred his money, but the laptop did not receive yet. At that time, he was still communicating with the suspect and but the suspect still updated his status on social media. However, he did not report this case to the police because they would be difficult to track the

2 Ollie. (2008). Membuat Toko Online dengan Multiply, Jakarta, Media Kita, p. 3.

3 Didik M . Arief Mansur \& Elisatri Gultom. (2005). Cyber Law Aspek Hukum Teknologi Informasi, Bandung: Refika Aditama, p. 5. 
suspect. In addition to loss his money, he did not believe that the police would handle this case. "he (suspect) forced that the good has been sent, and I also forced him but he reasoned that there was a problem with the shipping progress." Said sugi who lived in Caturtunggal, Depok. The DIY Director of Special Criminal Investigation Commissioner, Antonius Pujianito, stated that the reports of faking online business are always occurred on 3 or 5 cases in a day in the Regional Police of DIY. According to him, every report is always followed up with an investigation. "Within a month, it is about more than a hundred reports about faking online business. It is categorised as a high criminal case, and we are optimizing our investigation," the commissioner said. ${ }^{4}$

In a written statement survey received by TeknoLiputan6.com on Tuesday $(05 / 31 / 2016)$, Indonesia was in the highest position as a country whose internet users were victims of Cybercrime among 26 other countries surveyed. Furthermore, the second position is occupied by Vietnam and India with each 25 percent and 24 percent of internet users becoming targets of crime. The survey also found that 48 percent of consumers were targeted by faking actions designed to trick and get sensitive information and financial data for criminal acts. More surprisingly, it was almost half of internet users experienced financial threats during the 12-month survey period. ${ }^{5}$

Basically, many victims complain about their case to the Police because they feel they have been deceived or tricked, the actions taken by victims by reporting suspects of criminal acts of faking online business. Basically, it is done to obtain legal certainty in seeking justice and obtaining legal protection for them. Legal protection is an act of protection or an act for protecting from certain parties aimed at certain parties using certain methods as well. ${ }^{6}$

In our Constitution, we have mandated to the state to be able to protect our people from all threats and actions that are in disadvantageous to them, such as in Article $28 \mathrm{G}^{7}$ "Everyone has the right to personal, family, honour, dignity and property under their control, and also they have the right to get security and protection from the threat of fear for doing or not doing something that refers to a human right ".

Based on the above background analysis, the victims of a crime should get a protection so that the creation of legal certainty is the goal of the law itself. So on this occasion the author is interested in examining the issue of victims of

\footnotetext{
4 Sunartono. (2016). Setiap Hari Selalu Ada Korban Jual Beli Online Retrieved March 26, 2016 from http://m.semarangpos.com/2016/03/26/penipuan-online-setiap-hari-selalu-adakorban-jual-beli-online-704369 akses pada tanggal 26-10-2016

5 Agustin Setyo Wardani. (2016). Orang Indonesia Paling Banyak Jadi Korban Penipuan Online. Retrieved october 29, 2016 from http://tekno.liputan6.com/read/2519790/orang-indonesia-palingbanyak-jadi-korban-penipuan-online diakses pada tanggal 26-10-2016

6 Wahyu Sasongko. (2007). Ketentuan-ketentuan Pokok Hukum Perlindungan Konsumen, Bandar Lampung: Unila, p. 31.

7 Pasal 28 G Undang-Undang Dasar Negara Republik indonesia 1945.
} 
online business in terms of legal protection for victims of online business crime and what factors impede Legal Protection for victims of online business crime in Indonesia which will be described in a text entitled "Criminal Law Protection On Online Victims Of Victims".

\section{Method}

This research will be compiled using the type of normative juridical research, namely research focused on examining the application of rules or norms in positive law. Normative juridical, namely an approach that uses the conception of positivist legislation. ${ }^{8}$ This concept views the law as identical with written norms that are made and promulgated by an authorized institution or official. This conception views law as a normative system that is independent, closed and detached from real community life. ${ }^{9}$

This study uses a statute approach and a case approach. The legislative approach is used to determine the overall legal regulations, especially criminal law in Indonesia in the form of secondary data, which consists of the Republic of Indonesia Law Number 31 of 2014 concerning Amendments to Law Number 13 of 2006 concerning the Protection of Witnesses and Victims and Law of the Republic of Indonesia Number 19 Year 2016 concerning Amendments to Law Number 11 Year 2008 concerning Electronic Information and Transactions while the Case Approach aims to learn the application of legal norms or rules carried out in legal practice. Especially regarding cases that have been decided as can be seen in jurisprudence on cases that are the focus of research, namely criminal cases. ${ }^{10}$

Secondary legal materials used are consisting of books, research results, internet, legal facts, and statistics from official agency data. Legal recognition is also obtained through books written by criminal law experts.

\section{Analysis and Discussion}

The legal protection referred to here is that it protects victims from crimes that are approaching them. In cases of fraud in this online business, victims who suffer losses should be protected and given legal protection according to the applicable rules. In article 4 of the Consumer Protection Act letter h, it is stated that consumers have the right to obtain compensation, compensation and/ or reimbursement, if the goods and/ or services received are not in accordance with the agreement or not as they should.

In Article 1 number 3 of Law Number 31 of 2014 about the Amendments to Law Number 13 of 2006 about the Protection of Witnesses and Victims, stating that Victims are the people who suffered physical, mental, and/or economic losses caused by a crime.

8 Johnny Ibrahim. (2006). Teori dan Metodologi Penelitian Hukum Normatif, Malang: Bayumedia Publishing, p. 295

9 Ronny Hanitijo Soemitro. (1988). Metodologi Penelitian Hukum dan Jurimetri, Jakarta: Ghalia Indonesia, p. 13-14.

${ }^{10}$ Johnny Ibrahim, op. cit, p. 321. 
The law in principle is a regulation of the attitude (behaviour) of a person and society which against the violator is given a sanction by the state. Although the cyber is a virtual world, the law is still needed to adjust people's attitudes, at least there are two things for this: First, the people in cyberspace are people in the real world, people have values and interests for both individually and together that must be protected. Second, even though it occurs in cyberspace, transactions carried out by the community have the influence of it in the real world, both economically and non-economically. ${ }^{11}$

According to Arif Gosita, victim protection can be seen from the procedural right model that a victim has the right to obtain a protection for his personal security from the physical and psychological threat of other people, regarding the testimony that he will, is going or has been given for a crime. In addition, a number of rights are granted to victims, including the right to choose and determine any forms of protection and security, the right to obtain legal advice, the right to provide information without pressure, the right to obtain a new identity and residence, and the right to obtain the substitution of transportation costs as needed. ${ }^{12}$

Recently, the regulation used as the legal basis for cybercrime cases is the Law Number 11 of 2008 about Information and Electronic Transactions (ITE), while in terms of protecting consumers from developing crimes the rules currently use are the law No. 8 of 1999 about Consumer Protection. By the existence of this Law, it is expected to protect the people from technological crime in Indonesia, this is important to consider the number of technology users are increasingly rise from year to year.

Victims in faking online business usually experienced a loss in the form of material, where the victim has spent some money to buy something from an online business. In this case, the victim should be protected by the current rules in the Consumer Protection Act and ITE Law. In Article 4 of the Consumption Protection Act, consumer rights are:

a. the right to comfort, security and safety in consuming food and/or services;

b. the right to choose goods and/or services and obtain goods and / or services based on the exchange rate and conditions and also guarantees promised;

The legal protection referred to here is that it protects victims from crimes that are approaching them. In the case of online business fraud Rights and obligations are two words that have different meanings but cannot be separated from one another. There are no rights without obligations, on the contrary there is no obligation without rights. The existence of rights and

${ }^{11}$ Josua Sitompul. (2012). Cyberspace, cybercrime, cyberlaw, Tinjauan Aspek Hukum Pidana, Jakarta: PT. Tatanusa, p. 38.

12 Arif Gosita. (2004). Masalah Korban Kejahatan: Kumpulan Karangan. Jakarta: Bhuana Ilmu Populer, p. 21 
obligations has a deep meaning in relating between parties, whether individuals, groups, communities, or even the state. Not only in legal relations, but also relations in other fields such as social, economic, political and others. These victims who suffer losses should be protected and given legal protection according to the applicable rules. In article 4 of the Consumer Protection Act letter $h$, it is stated that consumers have the right to obtain compensation, compensation and/or reimbursement, if the goods and/or services received are not in accordance with the agreement or not as they should.

The meaning of rights can not be separated from the existence of interests, claims or authority. A person is said to have the right to an item if he has the authority or claim for the item and can be defended against the claims of the other party. Thus the victim's rights certainly relate to the interests or authority of the victim of something that can be maintained from claims or demands of other parties. The victim's rights arise in relation to the position of a party, namely the victim (individual, group, community, or state) in relation to the perpetrator and the criminal act. ${ }^{13}$

The rights of victims include:

a. The right to get compensation for the suffering that he has. The provision of compensation can be given by the perpetrator or other parties, such as a state or special institution established to deal with the problem of compensation for victims of crime.

b. The right to obtain coaching and rehabilitation

c. The right to obtain protection from the threat of the offender

d. The right to obtain legal assistance

e. The right to recover his rights

f. The right to obtain information about police investigations relates to the crime that befell the victim. ${ }^{14}$

In article 28 paragraph 1 of the ITE Law which explains that "Everyone intentionally and without rights spreads false and misleading news that results in consumer losses in electronic transactions". The threat mentioned in Article 45 Paragraph 2 "Any person who fulfills the elements referred to in article 28 paragraph (1) and (2) shall be punished with a maximum imprisonment of 6 (six) years or a maximum fine of Rp.1,000,000,000.00 ( one billion rupiah).

In the article there are consumer words which each consumer has rights. Well, generally known there are 4 kinds of consumer rights, namely:

1. The right to get security

2. The right to get information

3. The right to choose

4. Right to be heard

13 G Widiartana. (2009). Viktimologi Perspektif Korban Dalam Penanggulangan Kejahatan, Yogyakarta: Publisher, Universitas Atma Jaya, p. 54

14 Dikdik M Arif Mansur dan Elisatris Gultom. (2007). Urgensi Perlindungan Korban Kejahatan, Jakarta: Raja Grafindo Persada, p. 53 
These four basic rights are recognized internationally. In its development consumer organizations that are members of the International Organization of Consumer Union (IOCU) added to several rights, such as the right to get consumer education, the right to compensation, and the right to a good and healthy environment. ${ }^{15}$

In accordance with the contents of article 28 paragraph 1 of Law No. 11 of 2008 concerning consumer losses, the authors also cite several rights to consumers. Consumer rights as stated in article 4 of Law No. 8 of 1999 are as follows:

a. consumer rights get security rights

b. The right to get the right information

c. Right to be heard

d. The right to choose

e. The right to obtain goods and / or service products in accordance with the exchange rate provided

f. The right to get compensation

g. The right to get a legal settlement

$\mathrm{h}$. The right to get a good and healthy environment

i. The right to be protected from the negative consequences of cheating competition

j. The right to get consumer education. ${ }^{16}$

In cases of faking online transaction business crimes, faked victims will usually demand more material compensation so that the victim's rights are returned by the suspects. Even though the rights of victims of crime has been available, it does not mean that the obligations of victims of crime are ignored. Because it is through the role of victims and their families, it is expected that crime prevention can be achieved significantly. One of the protections is for the victims of crime and it is the rights of victims of criminal acts is to get compensation and restitution. The Compensation is given by the state to victims of gross human rights violations, while the restitution is a compensation for victims of criminal acts given by the suspects as a form of responsibility. ${ }^{17}$

There is a temporary opinion that criminals or lawbreakers in general do not need to be subject to criminality. In this opinion the criminal is a legacy of our past savagery, which should have been avoided. This opinion seems to be based on the view that crime is an act of treatment or imposition of cruel suffering. On the basis of the view of the description of cruel treatment and

15 Celina Tris Tiwi Kristianti. (2014). Hukum Perlindungan Konsumen, Jakarta: Sinar Grafika, p. $30-40$

16 Pasal 4 UU No. 8 tahun 1999 Tentang Perlindungan Konsumen

17 Chaerudin dan Syarif Fadilah. (2004). Korban Kejahatan dalam Perspektif Viktimologi dan Hukum Pidana Islam, Jakarta, Ghalia Pers,p. 55. 
transcending this boundary, there is the opinion that retributive theory or retaliation theory in terms of punishment is a relic of barbarian. ${ }^{18}$

The issue of the importance of protecting victims of crime has received serious attention, can be seen by the establishment of the Declaration of Basic Principles of Justice for Victims of Crime and Abuse of Power, which in one of its recommendations stated that the form of protection provided has expanded not only to victims of crime also protection of victims due to abuse of power. ${ }^{19}$

According to Stephen Schafer, the compensation arises from victims' requests and is paid by the community or is the responsible of the society, while The Restitution is more refers to the criminal, that is arising from criminal court decisions and paid by convicts or as the responsibility of the offender. ${ }^{20}$

In fact, the rights of consumers in this case are expressly stated in these rules, but in fact, the consumers often experienced losing in terms of business transactions in addition to a state of direct transactions. In this article, the writer analyses that the rights that should be obtained by consumers should be fulfilled and realized properly and it do not have the defects in terms of trading system, but the problem is that when consumers make transactions indirectly, they have not been expressly formulated in these rules.

If only we can see the purpose of a regulations made by the government is to protect the people from any crimes and it can protect the people from undesirable things (bad things). According to Satjipto Rahardjo, ${ }^{21}$ that legal protection is to provide protection to human rights that are harmed by others and its protection is given to the people so that they can enjoy all the rights given by law, or in other words, legal protection is a variety of legal efforts that must be given by the authorities law enforcers to provide security, both in mind and physically from any interferences and various threats from any party.

The legal protection referred to here is that it protects victims from any crimes that are approaching them. In the cases of fakes in this online business, victims who suffer losses should be protected and given legal protection based on the applicable rules. In article 4 of the Consumer Protection Act Letter $\mathrm{H}^{22}$ it is stated that the consumer has the right to get compensation, substitutions and/or replacement, if the goods and/or services received are not suitable whether their agreement deal or not as appropriate;

If we refer to this article, the consumers who are victims of all business/transaction crimes must get compensation in the form of

18 Siswanto Sunarso. (2012). Viktimologi Dalam Sistem Peradilan Pidana, Jakarta Timur, Sinar Grafika, p. 255

19 Dikdik M. Arief Mansur dan Elisatris Gultom. (2008). Urgensi Perlindungan Kejahatan Antara Norma dan Realita, Bandung, Rajawali Pers, p. 20

20 Stephen Schafer. (1962). Victim and Criminal, Random House, New York, p. 112.

21 Satjipto Rahardjo. (1993). Penyelenggaraan Keadilan dalam Masyarakat yang Sedang Berubah, Jurnal Masalah Hukum, p. 74.

${ }^{22}$ Article 4 Undang Undang Nomor 8 Tahun 1999 tentang Perlindungan Konsumen. 
compensation for the loss suffered by victims, but in the application of this article, many victims do not always grant this kind of protection. For example, the case that is happening (in this study) is the victim of a faking online business crime, until now the victim has never obtained his rights based on the rules that have been applied. Because this rule is more emphasis on the real business / transactions directly to the seller, meanwhile in terms of transaction online, there are still unclear rules about it.

According to the Radical Approach theory ${ }^{23}$ in Victimology that the State has an important role in terms of providing legal protection for victims. but there is a clear regulation which is adjusting the rights of existing victims. There are two elements of radical victimism:

a. Focus on the sociological and geographic aspects from the most vulnerable parts of the community

b. The impact experienced by victims as a result of the level of risk and vulnerability.

In this theory, it has actually been explained that the State is as a representative of all rights that occurs in this country, the State must give the best service to the people. From this theory, the current rules are still very weak in terms of eradicating and providing good legal protection to the victims of faking online business.

According to Muchsin, ${ }^{24}$ the legal protection is a matter that protects legal subjects through applicable legislation or rule and it is forced to implement it with a sanction. The Legal protection can be divided into two things, there are:

a. The protection of Preventive Law

The Protection provided by the government with the aim of preventing before the violations occurred. This is existed in the legislation with the intention to prevent a violation and provide signs or limitations in carrying out an obligation.

\section{b. The Protection of Repressive Law}

The Repressive legal protection is the final protection in the form of sanctions such as fines, imprisonment, and additional penalties given when a dispute has occurred or an offense has been committed. Based on all the legal protections mentioned above, Philipus M. Hadjon viewed that the protection of victims must be required because: ${ }^{25}$

${ }^{23}$ Di ambil dari bahan kuliah Prof. Dr. Marcus Priyo Gunarto, S.H., M.Hum dan Ibu Sri Wiyanti Eddyono

24 Muchsin. (2003). Perlindungan dan Kepastian Hukum bagi Investor di Indonesia, Surakarta: Universitas Sebelas Maret, p. 20.

25 Philipus M. Hadjon. (1987). Perlindungan Hukum Bagi Rakyat Indonesia. Surabaya: Bina Ilmu. p. 31 


\section{a. Social Contract Argument}

This Reasons are based on social contracts refers to the notion that the state monopolizes all social reactions to crime and prohibits acts which is done as a personal matter, in the occurrence of crimes and causes of victims, the state is obliged to pay attention to the needs of victims.

\section{b. Social Solidarity Argument}

This Reasons are based on social solidarity that are based on the definition that the state must protect its citizens who suffered any difficulties, in this case it can be through cooperation with the main society or it can be used the facilities provided by the state.

According to Arif Gosita, in seeking to fulfil the interests of victims of criminal acts must act as a shared responsibility of each member of the community based on their certain respective situations and conditions because; ${ }^{26}$

1. Justice services for justice seekers in the court of law, especially the victims of criminal justice are still not satisfactory, which is a manifestation of the lack of justice in court, which is a place to seek authenticity; the victim cannot claim compensation for suffering, which is the loss suffered. Therefore, this problem must not be allowed to continue considering the negative effects and the effectiveness of the criminal justice system. So, it is necessary to comprehend, the definition about this problem so that it can be handled responsibly.

2. The social problems approach in the perspective of sociology of law can help to provide a comprehension that can affect the current social problems, so that we can express and act appropriately as well as the against of these problems and how to overcome them.

3. Considering the ius constituendum regarding the criminal justice system that provides justice to the victims, where the victims can demand compensation or welfare services.

The importance of legal protection to victims of crime is something that cannot be separated from the environment of the state, the state or government is the end of all legal protection that will be given to victims of crime. In this case, those who are concerned with law enforcement, victims of online business crime have not yet found a comfortable place to rely on their rights to the state or government, it occurred because the clear regulation of the rights of victims of online business is unclear and also unclear about the victim's rights.

In terms of providing legal protection, it must be regulated in a good way as to create a certainty, benefit and justice in a legal state. The lack of regulation relating to the rights of victims of faking online business is one of the causes of the vulnerability of cases of fake or trickery under the disguise of an online

26 Arif Gosita. (1985). Masalah Korban Kejahatan, Jakarta: Akademika Pressindo, p. 112. 
business, because every victim who experienced the faking online business do not know how to get his rights. If we see in terms of law / rules that there is consumer protection related to online business is still very far away to get access to justice is different from other crimes, where victims can get a good legal protection because it is clear the rules govern it in a good way.

In this case, the government intervention is important in the terms of providing an easy access for every society who experienced crimes under the disguise of an online business so that other victims do not occur anymore.

\section{Conclusion}

Based on this study, we can conclude that:

That criminal legal protection against victims of online business crime in accordance with existing laws and regulations should guarantee the rights of victims of online business. The rights that must be obtained by online business victims are contained in Law Number 31 Year 2014 concerning Amendments to Law Number 13 Year 2006 concerning Witness and Victim Protection and Law Number 11 Year 2008 Information and Electronic Transactions (ITE).

That guaranteed rights have not been carried out optimally because the rules governing the protection of consumers of online businesses are unclear and do not provide space for victims to obtain criminal legal protection.

$$
* * *
$$

\section{Acknowledgements}

Thank you to the family who have given support in doing this research, and I do not forget to say to friends who are always loyal to help correct the translation of this text. Hopefully this article can be useful for future readers.

\section{References}

Chaerudin dan Syarif Fadilah, (2004), Korban Kejahatan dalam Perspektif Viktimologi dan Hukum Pidana Islam, Jakarta:Ghalia Pers.

Didik M . Arief Mansur \& Elisatri Gultom, (2005), Cyber Law Aspek Hukum Teknologi Informasi, Bandung: Refika Aditama.

Dikdik M. Arief Mansur dan Elisatris Gultom, (2008), Urgensi Perlindungan Kejahatan Antara Norma dan Realita, Bandung: Rajawali Pers.

Gosita, Arif, (1985), Masalah Korban Kejahatan, Jakarta: Akademika Pressindo. (2004), Masalah Korban Kejahatan: Kumpulan Karangan. Jakarta: Bhuana Ilmu Populer. 
Gosita, Arif, (1985), Masalah Korban Kejahatan, Jakarta, Akademika Pressindo.Ollie, 2008, Membuat Toko Online dengan Multiply, Jakarta: Media Kita.

Hadjon. Philipus M. (1987), Perlindungan Hukum Bagi Rakyat Indonesia. Surabaya: Bina Ilmu.

Kristianti, Celina Tris Tiwi, (2014), Hukum Perlindungan Konsumen, Jakarta: Sinar Grafika.

Muchsin. (2003), Perlindungan dan Kepastian Hukum bagi Investor di Indonesia, Surakarta: Universitas Sebelas Maret.

Raharjo, Agus, (2002), Cyber Crime Pemahaman dan Upaya Pencegahan Kejahatan teknologi, Bandung: PT. Citra Aditya Bakti.

Rahardjo. Satjipto, (1993), Penyelenggaraan Keadilan dalam Masyarakat yang Sedang Berubah, Jurnal Masalah Hukum.

Sasongko,Wahyu, (2007), Ketentuan-ketentuan Pokok Hukum Perlindungan Konsumen, Bandar Lampung: Unila.

Schafer, Stephen, (1962), Victim and Criminal, New York: Random House.

Sitompul,Josua, (2012), Cyberspace, cybercrime, cyberlaw, Tinjauan Aspek Hukum Pidana, Jakarta: PT. Tatanusa.

Sunarso, Siswanto, (2012), Viktimologi Dalam Sistem Peradilan Pidana, Jakarta Timur, Sinar Grafika.

Waluyo, Bambang, (2012), Viktomologi Perlindungan Korban dan Saksi, Jakarta: Sinar Grafika.

Yulia, Rena, (2003), Viktomologi Perlindungan Hukum Terhadap Korban Kejahatan, yogyakarta: Graha Ilmu.

\section{Legislation}

Undang-Undang Dasar Negara Republik indonesia 1945.

Kitab Undang-Undang Hukum Pidana (KUHP)

Undang Undang Republik Indonesia Nomor 8 Tahun 1999 tentang Perlindungan Konsumen.

Undang-Undang Republik Indonesia Nomor 11 Tahun 2018 Tentang Informasi dan Transaksi Elektronik 


\section{Lecture Materials and Website}

Di ambil dari bahan kuliah Prof. Dr. Marcus Priyo Gunarto, S.H., M.Hum dan Ibu Sri Wiyanti Eddyono

Sunartono. (2016). Setiap Hari Selalu Ada Korban Jual Beli Online Retrieved March 26, 2016 from http://m.semarangpos.com/2016/03/26/penipuanonline-setiap-hari-selalu-ada-korban-jual-beli-online-704369

Agustin Setyo Wardani. (2016). Orang Indonesia Paling Banyak Jadi Korban Penipuan Online. Retrieved october 29, 2016 from http://tekno.liputan6.com/read/2519790/orang-indonesia-paling-banyak-jadi-korbanpenipuan-online 